\title{
INFORMATION SYSTEMS OF SUPPORT OF PEDAGOGICAL CONTROL IN THE PHYSICAL EDUCATION OF STUDENTS
}

\author{
Victor Koryahin ${ }^{1 \mathrm{ABCD}}$, Yaryna Turchyn ${ }^{1 \mathrm{ABCD}}$, Oksana Blavt ${ }^{1 \mathrm{ABCD}}$, Lyubov Dolnikova ${ }^{1 \mathrm{ABCD}}$ \\ ${ }^{1}$ Lviv Polytechnic National University \\ Authors' Contribution: A - Study design; B - Data collection; C - Statistical analysis; D - Manuscript Preparation; E - Funds Collection
}

Corresponding Author: Oksana Blavt, E-mail: oksanablavt@ukr.net

Accepted for Publication: December 20, 2020

Published: December 25, 2020

DOI: 10.17309/tmfv.2020.4.02

\begin{abstract}
The study is to substantiate and implement modern electronic automated monitoring systems to improve the testing of speed-strength abilities in the process of physical education.

Materials and methods. To solve the research tasks used the methods of comparing and contrasting are used and analysis, synthesis, abstraction, formalization and technical modeling.

Results. The developed capacitive sensor device for speed control is presented. The device is built on a combination of modern nanotechnology and microprocessor systems. As part of the device, the array of active electrodes with digital output registers an input signal from a marker placed on the monitoring object and whose position changes during the exercise. Then the digital signal through the interface and the communication line, goes to the signal converter, where it is processed and wireless transmission devices signal goes to the personal computer, where the result of the exercise is displayed.

Conclusions. Use in pedagogical control of the physical education process of the developed device provides a reliable objective test data with little loss of time to ensure the quality of control.

Keywords: testing, control, physical education, student, vertical stability of the posture, device, innovation, measurements.
\end{abstract}

\section{Introduction}

Problem statement. The effectiveness of physical education of students depends largely on the promptness and timely systematic process of obtaining information about their physical condition - pedagogical control (Koryahin, Mukan, Blavt, \& Virt, 2019). Addressing the problem of pedagogical control is explained by its theoretical and practical importance for optimal management of the efficiency of physical education, as a factor of health of student youth.

A special place in the study of physical condition, as a correlator of the effectiveness of physical training, is the problem of factors that determine its level and features (Zatsiorsky, 2006). Its level is the result of a complex interaction of many factors, the contribution of which is determined by the concerted activity of the set of functional systems in the process of physical training.

The state of sensory systems and adaptation to training loads on indicators of coordination abilities is of great

(c) Koryahin, V., Turchyn, Ya., Blavt, O., Dolnikova, L., 2020. importance (Deliagina, Orlovsky, Zelenin, \& Beloozerova, 2006). An important source of information on the state of coordination abilities and the necessary condition that provides an assessment of the physical condition of the organism, its level of physical performance and reserve capabilities, is the study of one of the manifestations of equilibrium - the ability to maintain the vertical stability of the posture in the practice of physical education of students (Huxham, Goldie, \& Patla, 2001; Matin, Yalfani, Gandomi, Abbasi, \& Parmoon, 2014).

Considering that the efficiency, pedagogical management of the process of physical preparation of students depends on the quality, timeliness and content of the received control information (Koryahin, Blavt, \& Ponomaryov, 2019), the expediency and necessity of research of methods of realization of control procedures of equilibrium control during their physical education is substantiated.

In the national-state implementation of a topical study of the challenge under consideration, the achievement of the required for physical development, as a factor of health, increased student youth. In pedagogical practice, the physical increase in the level of urgent reliability of control of their functional state is an urgent problem today. 
Analysis of recent research and publications. The relevance of the answer to solving the problems with the most modern low-level factors, among which the confidence of domestic and foreign researchers to the knowledge and interpretation of data related to the development of equilibrium as a result of physical growth, was achieved (Di Stefano, Clark, \& Padua, 2009; Karakaya, Rutbİl, Akpinar, Yildirim, \& Karakaya, 2015). The study of the source had on all the investigated methods that correspond to the coordination (Schmidt \& Lee, 2011; Huxham, Goldie, \& Patla, 2001), analyzing the practical development of equilibrium that exist when using a physical and functional station of the student (Plisky, Rauh, Kaminski, \& Underwood, 2006; Matin, Yalfani, Gandomi, Abbasi, \& Parmoon, 2014), methodological correction of the third data downloaded by the shown coordinators vertical level (Cloak, Nevill, \& Wyon, 2016; Magill, 2007; Sell, 2012).

The analysis of the functional state of work within the physical direction represents various aspects of these problems. Each specific state can be described for different manifestations, which are used to change different functions of the physical system (Volery, Singh, de Bruin, List, Jaeggi, \& Baur, 2017; McKeon \& Hertel, 2008). Observed, interpreting the basic physical laws of physical activity, regulate the organs of the body, preventing the weathered, it is possible to achieve the possibility of restoring the vertical work established on the central nervous system (Cuğ, Özdemir, \& Ak, 2014; Giboin, Gruber, \& Kramer, 2015).

The ability to maintain vertical posture stability as a manifestation of equilibrium is an important physiological factor that determines the effectiveness of students' physical fitness in their physical education (Koryahin, Blavt, \& Ponomaryov, 2019). In almost every type of physical activity, equilibrium manifests itself in various positions of the body, in static and dynamic conditions, in the presence of a support and in a supportive position (Deliagina, Orlovsky, Zelenin, \& Beloozerova, 2006; Hrysomallis, 2011). This is due to the growing interest in the development of information systems to control and analyze the various manifestations of equilibrium (Boloban \& Mistulova, 2000; Plisky, Gorman, Butler, Kiesel, Underwood, \& Elkins, 2009). However, the existing list of available techniques is slowly being introduced into the practice of physical education of students.

The analysis of the specialized scientific and methodological literature confirms the importance of pedagogical control over the state of physical fitness of students as the basis of physical education management (Koryahin \& Blavt, 2018; Thomas, Nelson, \& Silverman, 2015), but confirms the imperfection of motor tests, which are the basis of the software and methodological support of the physical education process (Schmidt \& Lee, 2011). Practices that are not unified (such as electrocardiography) (Reiman \& Manske, 2009) have several disadvantages and limitations, the main one being the subjectivity of the test process. In addition, there are doubts about the reliability of the analysis and evaluation of the results obtained by testing, and therefore the effectiveness of a holistic process of physical education of students. The scholars' claim (Koryahin, Mukan, Blavt, \& Virt, 2019; Silverman, 2011) that the system of controlling the development of students' coordination skills in higher education institutions put into practice does not contribute to the correction and realization of the educational and recreational tasks of their physical education.
Ukrainian scientists justify the need to raise the level of scientific research in physical education, integrating them into the world practice of informatization, is extremely important, because it is an indicator of the development of the industry (Kachan, 2017; Shuba \& Shuba, 2017). In view of the above, innovations in the field of physical education, aimed at introducing in his progress of scientific achievements and dissemination of the best experience of informatization, as a factor of ensuring its effectiveness (Zatsiorsky, 2006), are of exceptional relevance.

In view of the above, introducing innovations into this process is considered to be a promising area of improvement of control means. As noted, innovative tendencies at the present stage of scientific and technological progress cause powerful evolutionary changes in all branches of higher education knowledge in the context of its modernization (Morze \& Kocharian, 2014). Given that the most relevant topic for discussion in science today is the topic of innovation (Donath, Roth, Zahner, \& Faude, 2017; Koryahin, Blavt, \& Ponomaryov, 2019), let us note the discreet consideration of issues in the control of physical education of students in the literature, which requires studies of adaptation and implementation of new information services, which are recognized as relevant and developmental.

The purpose of the article is to substantiate and implement an information-measuring tool to control the level of development of the ability to maintain the vertical stability of postures of students in the process of physical education.

\section{Materials and methods}

Theoretical and methodological basis of the study are: conceptual provisions of the theory and methods of physical education and physical culture (Di Tore, Schiavo, D'isanto, 2016; Zatsiorsky, 2006); the theory of testing motor abilities (Reiman \& Manske, 2009; Wood \& Zhu, 2006); theories of pedagogical control in physical education (Silverman, 2011); theory of evaluation of test tests (Zatsiorsky, 2006; Zhu, 1998), the theory of functional systems (Lauber \& Keller, 2014).

In order to achieve the goal of the research, the ideas of introduction of innovations in physical education (Kachan, 2017; Shuba \& Shuba, 2017), conceptual provisions on modernization of approaches to the organization, formation and realization of the content of control (Zatsiorsky, 2006) in this process were used in order to ensure the effective functioning of the function of managing the process of physical training.

The innovative approach was ensured by the introduction of the latest technologies and information services into the control process. The modernization envisaged the creation of a new control information system based on microprocessor devices and systems that increase the capabilities of this process (Mykytyuk, Fechan, Shymchyshyn, Rudyi, Nazarenko, \& Petryshak, 2012).

The use of ideas of a comprehensive approach is due to the need to create new control technologies from the standpoint of this approach for the qualitative modernization of the testing process (updating of content, forms, methods, tools) (Zatsiorsky, 2006).

The synergistic approach gave grounds to consider the control in physical education as a structure with its own logic of organization with the integral logical unity of the components of the methodological apparatus for development and integration into the process of control of innovative technologies for advancing. 
The complex of theoretical and practical methods was used to solve the set tasks during the research:

- $\quad$ at the theoretical level general scientific: analytical and problem-oriented analysis to obtain theoretical and empirical material; synthesis and synthesis of information presented in the scientific literature to establish methods, levels of implementation, research approaches to the formation of research provisions;

- at the empirical level - technical modeling to create an innovative hardware and software control with algorithmic and software to be studied; pedagogical testing of the level of development of the ability to maintain the vertical stability of the posture.

To perform pedagogical testing, we used the test of the ability to maintain the vertical stability of the posture. The test is that one-leg balancing is performed on a special stand. The student stands on any stand and tries to balance on it. The other leg is bent at the knee and pulled up to the buttocks with a brush of the same name. If you lose your balance, you must start the test first. The test is repeated as many times as necessary to allow the total balancing duration to be one minute (Thomas, Nelson, \& Silverman, 2015).

\section{Results}

To realize the idea of research, it should be noted that the ability to maintain a steady vertical position of the body is a complex dynamic phenomenon (Deliagina, Orlovsky, Zelenin, \& Beloozerova, 2006). The development of such a phenomenon is ensured by the functional state of the organism, the physical development and the development of coordination abilities. Performing elementary simple movements requires a sufficiently high level of equilibrium development, which ensures that vertical stability is maintained. It seems legitimate, therefore, that the manifestations of equilibrium are the subject of numerous interdisciplinary studies (Bressel, Yonker, Kras, \& Heath, 2007; Cloak, Nevill, \& Wyon, 2016; Bressel, Yonker, Kras, \& Heath, 2007). Therefore, the need for information on the ability to maintain the vertical stability of students' postures is justified by the diagnostic informativeness of the assessment of the results of physical education (Di Tore, Schiavo, \& D'isanto, 2016).

However, a test exercise that takes into account the number of attempts that students spend on steady balancing on a support for 1 minute is a fairly subjective assessment technique. In particular, the moment of loss of posture stability is set visually during control. There is a likelihood of error in determining the results of the exercise when calculating the number of attempts that students spend on maintaining a stable position and balancing on the support. This makes it difficult to obtain reliable informative results of control, respectively, they can not testify to the effectiveness of the educational process of physical education of students.

In the future, the experimental study was aimed at eliminating a number of problematic factors in the implementation of the test process. The results of the scientific search are embodied in the innovation and information support of the implementation of the test control of the ability to maintain the vertical stability of the postures in order to obtain objective reliable information.

An electronic device for automated control of test exercise execution was developed for the purpose of the research purpose. The device is mounted on the bottom surface of the stand on which the student balances. The device uses four strain gauges.
As elements of technical systems, the sensors in our device perform the functions of measuring, signaling, adjusting, controlling the device. They are a sensitive component of the measuring system of the device, which are used for indirect measurement of force, pressure, weight, mechanical stress (Mykytyuk, Fechan, Shymchyshyn, Rudyi, Nazarenko, \& Petryshak, 2012).

Tensosensors are a structurally separated part of a developed device that receives information, and therefore has the self-sufficiency to accomplish this task, and certain metrological characteristics. The use of strain gauges in our development is substantiated by their properties of rapidly changing shapes, high electrical resistivity and high strain sensitivity. The high level of strain sensing provides the ability of the sensor to respond to strain measurements under the action of pressure. A distinctive feature of such sensors used in the developed device is their low consumption (operation in the mode of microcurrents), which made it possible to use autonomous power in the device (Hotra, Mykytyuk, \& Sushynskyy, 2010).

To ensure the operation of the strain gauge, discrete algorithms for the analysis of input information signals are used, which significantly improves the energy consumption of the sensor (Hotra, Mykytyuk, Diskovskyi, Barylo, \& Vezyr, 2018). In the device, the high-precision gauges register the force of pressure on the stand of the student's foot, which, before the test begins, stands on the stand with one leg and balances its body. In this position, the signal from the sensors stabilizes for two to three seconds and a test readiness message is displayed. Information about the magnitude of the pressure is supplied to the wireless module WI-FI, which is also located at the bottom in the middle of the stand. Once it is confirmed (from the PC keyboard), a timer is triggered to record the time of vertical posture retention. Loss of posture stability causes a change in the value of the initial values of the sensors. The module that is part of the device transmits data to a personal computer or other compatible device (such as a smartphone). The software runs the test and determines the duration of the test. The end of the test occurs when the values of the initial values of the sensors are changed - in automatic mode or with the help of software through the user interface - in manual mode. In automatic mode, the sensors will record a sharp decrease in load as part of the student's body weight will be transferred to the second leg. In addition, the program monitors short-term deviations of sensor values, avoiding the possibility of rebalancing. In automatic mode, or with the help of software through the user interface after a time (one minute), the fixation of the results of the test stops (Fig. 1).

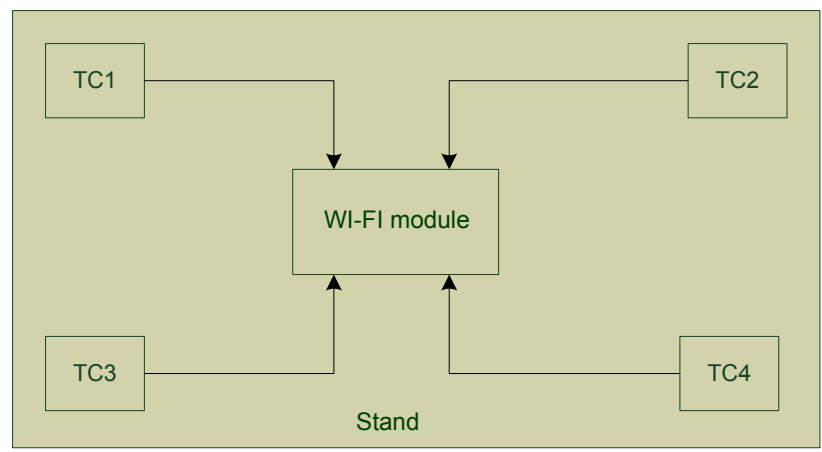

Fig. 1 Flowchart of the electronic part of the device (TC1 - TC4 - Sensors 1-4) 
The operation of the automated control unit, the accumulation and reading of the test results is carried out remotely via the Bluetooth interface between the personal computer and the measuring device. To do this, use developed software. Using the software developed for processing the test results, the test is run and the duration of the test is determined.

The software implementation of the model significantly improves performance by reducing the ergonomics of the interface and reducing the number of operations. The interface includes a power controller as well as internal built-in memory to store the code. The program provides: the choice of parameters of the protocol of Connect interface, control of start and end of measurement - Start / Stop, calibration of process of measurement - Calibration, digital - Indicator and graphic Plot visualization of results, saving Data save and erasing Date clear data, information about research algorithm - About.

Using the software implement digital and graphical visualization of results, storage and disposal of data, information about the algorithm of testing. The function of this provision is to form an integrated database of test controls, which facilitates their replication, processing and interactive analysis using statistical and mathematical methods and algorithms. In this way, the accumulation, updating, correction and multidimensional use of a large amount of control information is carried out.

At the end of the exercise, the results of the test are displayed on the screen using the software user interface and the value of which assess the ability to maintain the vertical stability of the posture. The application interface is comfortable and ergonomic. Measurement results are processed and visualized as graphs or figures on a display screen, printed on a form, saved to files for storage.

Developed electronic device for automated control of the level of development of the ability to maintain the vertical stability of student poses is able to detect the information component of signals at the level of natural interference. If necessary, subject to the use of special digital signal processing (correlation analysis, etc.), the methods of technical development can detect the information component of the signals and slightly below the level of natural interference. This is ensured by the high automatic sensitivity detection threshold and the quasi-optimal method of receiving signals implemented by the automated control devices, as well as by the selection of an automatic detection threshold adapted to each subband (Mykytyuk, Fechan, Shymchyshyn, Rudyi, Nazarenko, \& Petryshak, 2012).

The personal computer also records, visualizes and analyzes the results of the evaluation in accordance with the algorithm of functioning of the internal software. In addition to promptly displaying the results of controls, the device makes it possible to store their values in internal memory to analyze the dynamics of the ability to maintain the vertical position of the body. Their further archiving is carried out in the infrastructure of the centers of data storage and processing in a personal text format for each student and is accessible to them.

The analysis of the obtained results of the control of the level of development of the ability to maintain the vertical stability of the postures is synthesized with a visual form of presentation, which provides a convenient view of the structure of the obtained results, their dynamics and accounting of the summary information during the period of physical education of students. This greatly increases the informative content of the control.

\section{Discussion}

Our research expands information on pedagogical control of students' physical education (Di Tore, Schiavo, D'isanto, 2016; Morze \& Kocharian, 2014). We support scientific approaches to the need for prompt reliable information about the dynamics of changes in physical and functional fitness of the student, the absence of which reduces the effectiveness of the physical preparation process (Silverman, 2011; Shyrobokov, Malinina, \& Malinin, 2012). The procedure of pedagogical control is a classification of the present state of motor and functional readiness, on which the decision-making process in the management of physical education (lean) depends (Ivashchenko, Khudolii, Iermakov, \& Harkusha, 2017; Ivashchenko, 2020).

Despite the great interest of scientists, a number of problematic issues of test control in physical education of students have not yet been resolved. We have not found many scientific papers in this field in the specialized literature. The results of our study add to the fact that managing the process of physical education of students is more effective if the teacher has reliable information about the results of a particular stage of classes (Anikieiev, 2015; Matin, Yalfani, Gandomi, Abbasi, \& Parmoon, 2014). The obtained results of the conducted scientific intelligence supplement the data on pedagogical control as a significant mechanism of influence and management of the process of physical education of students (Kachan, 2017; Shyrobokov, Malinina, \& Malinin, 2012).

We align our study with the findings of a number of scientists on the significant impact on the quality of physical education of the development of coordination abilities (Koryahin, Mukan, Blavt, \& Virt, 2019; Reiman \& Manske, 2009; Zatsiorsky, 2006). Equally important are the indicators of equilibrium as a correlator of physical condition (RutkowskaKucharska \& Wuchowicz, 2018; Schmidt \& Lee, 2011). Indicators of the level of development of the ability to maintain the vertical stability of students' postures are the basis of the conclusions about the need to make adjustments to the program of classes in order to scientifically justify the training process and increase its effectiveness (Anderson \& Behm, 2005; Plisky, Rauh, Kaminski, \& Underwood, 2006).

In the numerous list of scientific works the introduction of innovations in the control process is considered (Di Tore, Schiavo, \& D’isanto, 2016; Ringhof \& Stein, 2018) as an opportunity to increase the efficiency of physical education classes. The obtained results expand and supplement the data on the need to use the latest technologies in the control of physical education of students as an innovative vector of the development of the physical education system in higher education institutions (Anikieiev, 2015; Koryahin \& Blavt, 2018). We support scientific approaches that informatization of modern education necessitates the development of a new model of physical education based on interdisciplinary integration processes of the use of the latest technologies (Kachan, 2017; Zatsiorsky, 2006). The research conducted integrates the idea that an important direction in the development of physical education of students is informatization, as a factor in ensuring the effectiveness of this process in general (Morze \& Kocharian, 2014). 
We support scientific thinking about the need to innovate, fundamentally new approaches to the development of control theory in physical education (Feldman, 2016; Li, Ye, Shen, Xie, \& Li, 2018), and offer a qualitatively new approach to the study of control implementation in this area of knowledge. In the methodological support of the control process of using automated systems, it is possible to reasonably build information models of the process of physical preparation of students (Kachan, 2017; Shyrobokov, Malinina, \& Malinin, 2012).

Developed in the course of experimental research, an electronic device for automated control of the level of development of the ability to maintain the vertical stability of postures of students in the process of physical education can be useful in the study of the coordination abilities of athletes, to give a quantitative and qualitative assessment of this ability, to supplement knowledge of sports technique exercises. In addition, its practical application will allow specialists to monitor the quality of exercise training associated with the complex motor skill of maintaining body balance and to draw conclusions about the orientation of children to engage in complex coordination sports.

\section{Conclusions}

Intensive social development, increasing the impact of scientific and technical process in science necessitates a significant improvement in the quality of scientific research and the implementation of dramatic changes in the organization of control and analysis of the results of physical education. The dominant tendency of development of the modern system of physical education of students is conformity to modern development, which is embodied in its transition to information support. The integration of innovative information and measurement resources into the physical education of students forms an information space of control at a new level, providing intensification of the test process.

According to the results of a scientific search, an information-measuring device for controlling the level of development of the ability to maintain vertical posture stability in the process of physical education is presented. The developed electronic automation control device integrates the latest developments in electronic and microprocessor technology, intelligent measurement programming, computer technology, modeling, hardware and software design. The practical application of the presented device ensures the unification and intensification of the process of obtaining and processing the test results in real time. Thus, the elimination of a number of problematic factors of the control process based on the integration of multiple functions technology into a single system is ensured. An attempt has been made to increase the effectiveness of control in the physical education of students by promptly analyzing and interpreting large amounts of quantitative testing information.

Using information-measuring tool to control the level of development of the ability to maintain the vertical stability of postures of students in the process of physical education can provide a qualitatively new step in the methods and didactics, organization and practical implementation of control in the physical education of students.

\section{Conflict of interest}

The authors state no conflict of interest.

\section{References}

American College of Sports Medicine. (2013). ACSM's Guidelines for Exercise Testing and Prescription. 9th ed. Philadelphia. PA: Lippincott Williams \& Wilkins.

Anderson, K., \& Behm, D.G. (2005). The impact of instability resistance training on balance and stability. Sports Med, 35, 43-53. https://doi.org/10.2165/00007256-200535010-00004

Anikieiev, D.M. (2015). Criteria of effectiveness of students' physical education system in higher educational establishments. Physical education of students, 19(5), 3-8. https://doi.org/10.15561/20755279.2015.0501

Boloban, V., \& Mistulova, T. (2000). Stabilography: achievements and prospects. Science in Olympic Sports. Specialist, issue GNIIFKS, 5-13.

Bressel, E., Yonker, J.C., Kras, J., \& Heath, E.M. (2007). Comparison of static and dynamic balance in female collegiate soccer, basketball, and gymnastics athletes. Journal of Athletic Training, 42(1), 42-46.

Cloak, R., Nevill, A., \& Wyon, M. (2016).The acute effects of vibration training on balance and stability amongst soccer players. Journal of Physical Education and Sport, 16(1), 2026. https://doi.org/10.1080/17461391.2014.973912

Cuğ, M., Özdemir, R.A., \& Ak, E. (2014). Influence of leg dominance on single-leg stance performance during dynamic conditions: An investigation into the validity of symmetry hypothesis for dynamic postural control in healthy individuals. Turkish Journal of Physical Medicine \& Rehabilitation, 60(1), 22-26. https://doi.org/10.5152/tftrd.2014.59354

Deliagina, T.G., Orlovsky, G.N., Zelenin, P.V., \& Beloozerova, I.N. (2006). Neural bases of postural control. Physiology (Bethesda), 21, 216-225. https://doi.org/10.1152/physiol.00001.2006

Di Tore, P.A., Schiavo, R., \& D’Isanto, T. (2016). Physical education, motor control and motor learning: theoretical paradigms and teaching practices from kindergarten to high school. Journal of Physical Education and Sport, 16(4), 1293-1297. https://doi.org/10.7752/jpes.2016.04205

Di Stefano, L.J., Clark, M.A., \& Padua, D.A. (2009). Evidence supporting balance training in healthy individuals: A systemic review. Journal of Strength and Conditioning Research, 23(9), 2718-2731. https://doi.org/10.1519/JSC.0b013e3181c1f7c5

Donath, L., Roth, R., Zahner, L., \& Faude, O. (2017). Slackline training (balancing over narrow nylon ribbons) and balance performance: A meta-analytical review. Sports Medicine, 47(6), 1075-1086. https://doi.org/10.1007/s40279-016-0631-9

Feldman, A.G. (2016). The Relationship Between Postural and Movement Stability. Adv Exp Med Biol., 957, 105-120. https://doi.org/10.1007/978-3-319-47313-0_6

Giboin, L.-S., Gruber, M., \& Kramer, A. (2015). Task-specificity of balance training. Human Movement Science, 44, 22-31. https://doi.org/10.1016/j.humov.2015.08.012

Hotra, Z., Mykytyuk, Z., Diskovskyi, I., Barylo, G., \& Vezyr, F. (2018). Optic sensors of enzymes with sensitive 
environment based on cholesterol liquid crystals. In 14th International Conference on Advanced Trends in Radioelectronics, Telecommunications and Computer Engineering, TCSET, 716-719. https://doi.org/10.1109/TCSET.2018.8336300

Hotra, Z., Mykytyuk, Z, \& Sushynskyy, O. (2010). Sensor systems with optical channel of information transferring. Przeglad Elektrotechniczny, 86(10), 21-23.

Huxham, F.E., Goldie, P.A., \& Patla, A.E. (2001). Theoretical considerations in balance assessment. Australian Journal of Physiotherapy, 47(2), 89-100. https://doi.org/10.1016/S0004-9514(14)60300-7

Ivashchenko, O., Khudolii, O., Iermakov, S., \& Harkusha, S. (2017). Physical exercises' mastering level in classification of motor preparedness of 11-13 years old boys. Journal of Physical Education and Sport, 17(3), 1031-1036. https://doi.org/10.7752/jpes.2017.03158

Ivashchenko, O. (2020). Research Program: Modeling of Motor Abilities Development and Teaching of Schoolchildren. Teoriâ ta Metodika Fizičnogo Vihovannâ, 20(1), 32-41. https://doi.org/10.17309/tmfv.2020.1.05

Kachan, O.A. (2017). Implementation of innovative technologies in physical culture and sports activities of educational institutions. Slavyansk:Vytoky, 138. (in Ukrainian)

Karakaya, M.G., Rutbİl, H., Akpinar, E., Yildirim, A., \& Karakaya, İ.Ç. (2015). Effect of ankle proprioceptive training on static body balance. Journal of Physical Therapy Science, 27(10), 3299-3302.

Koryahin, V., \& Blavt, O. (2018). The Use of Information and Communication Technology for Determining the Level Mobility in Joint in Physical Education of Students. Teoria ta Metodika Fizičnogo Vihovanna, 18(3), 107-113. https://doi.org/10.17309/tmfv.2018.3.01

Koryahin, V., Blavt, O., \& Ponomaryov, S. (2019). Innovative Intestification of Testing of Strength Endurance in Physical Education of Students With Chronic Diseases. Teoriâ ta Metodika Fizičnogo Vihovannâ, 19(3), 116-122. https://doi.org/10.17309/tmfv.2019.3.02

Koryahin, V., Mukan, N., Blavt, O., \& Virt, V. (2019). Students' coordination skills testing in physical education: ICT application. Information Technologies and Learning Tools, 70(2), 216-226. https://doi.org/10.33407/itlt.v70i2

Lauber, B., \& Keller, M. (2014). Improving motor performance: Selected aspects of augmented feedback in exercise and health. European Journal of Sport Science, 14(1), 36-43. https://doi.org/10.1080/17461391.2012.725104

Li, Z., Ye, L., Shen, J., Xie, K., \& Li, Y. (2018). Strain-gauge sensoring composite films with self-restoring waterrepellent properties for monitoring human movements. Composites Communications, 7, 23-29. https://doi.org/10.1016/j.coco.2017.12.007

Magill, R.A. (2007). Motor learning and control: Concepts and applications (8th ed.). McGraw-Hill International Edition.

Matin, B.K., Yalfani, A., Gandomi, F., Abbasi, H., \& Parmoon, A. (2014). Neuromuscular training as the basis for developing the level of the static and dynamic balance in selected students of physical fitness team of Kermanshah.
International. Journal of Sports Sciences \& Fitness, 4(1), 20-38.

McKeon, P.O., \& Hertel, J. (2008). Systematic review of postural control and lateral ankle instability, part I: Can deficits be detected with instrumented testing. Journal of Athletic Training, 43(3), 293-304. https://doi.org/10.4085/1062-6050-43.3.293

Morze, N., \& Kocharian, A. (2014). ICT competence standards for higher educators and quality assurance in education. Information Technologies and Learning Tools, 5. (in Ukrainian)

Mykytyuk, Z., Fechan, A., Shymchyshyn, O., Rudyi, A., Nazarenko, V., \& Petryshak, V. (2012). Sensor network based on gas smart sensors for environmental monitoring. Modern Problems of Radio Engineering, Telecommunications and Computer Science - Proceedings of the 11th International Conference, TCSET'2012, 503-504.

Plisky, P.J., Rauh, M.J., Kaminski, T.W., \& Underwood, F.B. (2006). Star excursion balance test as a predictor of lower extremity injury in high school basketball players. Journal of Orthopaedic and Sports Physical Therapy, 36, 911-919. https://doi.org/10.2519/jospt.2006.2244

Reiman, M.P., \& Manske, R.C. (2009). Functional testing in human performance. Champaign IL : Human Kinetics.

Ringhof, S., \& Stein, T. (2018). Biomechanical assessment of dynamic balance: Specificity of different balance tests. Human Movement Science, 58, 140-147. https://doi.org/10.1016/j.humov.2018.02.004

Rutkowska-Kucharska, A., \& Wuchowicz, K. (2018). Body stability in synchronized swimming. Human Movement, 4, 29-35. https://doi.org/10.1515/humo-2016-0008

Schmidt, R.A., \& Lee, T.D. (2011). Motor control and learning. A behavioral emphasis (5th ed.). Champaign: Human Kinetics.

Sell, T.C. (2012). An examination, correlation, and comparison of static and dynamic measures of postural stability in healthy, physically active adult. Physical Therapy in Sport, 13(2), 80-86. https://doi.org/10.1016/j.ptsp.2011.06.006

Silverman, S. (2011). Teaching for student learning in physical education. J Phys Educ Recreat Dance, 82, 29-34.

Shuba, L., \& Shuba, V. (2017). Modernization of physical education of student youth. Physical education of students, 21(6), 310-316. https://doi.org/10.15561/20755279.2017.0608

Shyrobokov, D., Malinina, Ya. \& Malinin, V. (2012). Features and Disadvantages of Pedagogical Control of Physical Education of Secondary and Higher School Students, Innovations and Modern Technologies in the Education System, 2, 250-252. (in Russian)

Thomas, J.R, Nelson, J.K, \& Silverman, S.J. (2015). Research methods in physical activity, 7th ed. Champaign: Human Kinetics.

Volery, S., Singh, N., E.D. de Bruin, List, R., Jaeggi, M.M., \& Baur, B.M. (2017). Traditional balance and slackline training are associated with task-specific adaptations as assessed with sensorimotor tests. Journal of Physical Education and Sport, 17(7), 838-846.

https://doi.org/10.1080/17461391.2017.1317833 
Wood, T., \& Zhu, W. (2006). Measurement Theory and Practice in Kinesiology. Human Kinetics.

Zatsiorsky, V.M. (2006). Kinetics of Human Motion. Champaign, IL: Human Kinetics.

Zatsiorsky, V.M. (2006). Fundamentals of sports metrology.

Moscow: Physical Culture and Sport. (in Russian)
Zhu, W. (1998). Measurement and Evaluation. Test Equating: What, Why, How? Research Quarterly for Exercise and Sport, 69(1), 11-23. https://doi.org/10.1080/02701367.1998.10607662

\title{
ІНФОРМАЦІЙНІ СИСТЕМИ СУПРОВОДУ ПЕДАГОГІЧНОГО КОНТРОЛЮ У ФІЗИЧНОМУ ВИХОВАННІ СТУДЕНТІВ
}

\author{
Віктор Корягін ${ }^{1 \mathrm{ABCD}}$, Ярина Турчин ${ }^{1 \mathrm{ABCD}}$, Оксана Блавт ${ }^{1 \mathrm{ABCD}}$, Любов Дольнікова ${ }^{1 \mathrm{ABCD}}$ \\ ${ }^{1}$ Національний університет «Львівська політехніка»
}

Авторський вклад: А - дизайн дослідження; В - збір даних; C - статаналіз; D - підготовка рукопису; Е - збір коштів

Реферат. Стаття: 7 с., 1 рис., 45 джерел.

Мета дослідження - обгрунтування та реалізація інформаційно-вимірювального засобу контролю рівня розвитку здатності збереження вертикальної стійкості пози студентів у процесі фізичного виховання.

Матеріали та методи. Представлено методи, використані у дослідженні, серед яких теоретичний аналіз наукової літератури, аналіз і синтез, індукція та дедукція, співставлення, порівняння та рефлексія, метод систематизації та узагальнення. Для вирішення дослідницьких завдань використано методи технічного моделювання.

Результати здійсненого наукового пошуку втілено у інноваційно-інформаційному забезпеченні реалізації тестового контролю здатності збереження вертикальної стійкості пози задля одержання об'єктивної достовірної інформації контролю у режимі реального часу. Представлено розроблений електронний пристрій автоматизованого контролю виконання тестової вправи у якому інформація тестування реєструється тензорезисторами та передається у персональний комп’ютер за допомогою структурної мережі передавання даних. Передача результатів тестування здійснюється безпровідними пристроями передавання інформації - Bluetooth. Розроблене програмне забезпечення у пристрої контролю формує інтегровану базу даних тестування здатності збереження вертикальної стійкості пози, у якій налагоджена їхня реплікація, обробка та інтерактивний аналіз.

Висновки. Ефективність застосування представленого засобу автоматизованого контролю рівня розвитку здатності збереження вертикальної стійкості пози студентів в процесі фізичного виховання забезпечено усунення низки проблемних чинників на основі інтегрувальної технології множинних функцій в єдину інформаційно-вимірювальну систему задля реалізації термінового оперативного об'єктивного контролю.

Ключові слова: тестування, контроль, фізичне виховання, студент, вертикальна стійкість пози, пристрій, інновації, вимірювання.

\section{Information about the authors:}

Koryahin V.: koryahinv@meta.ua; https://orcid.org/0000-0003-1472-4846; Department of Physical Education, Lviv Polytechnic National University, Bandera St, 12, Lviv, 79013, Ukraine.

Turchyn Y.: turchynj@ukr.net; http://orcid.org/0000-0002-9114-1911; Department of Physical Education, Lviv Polytechnic National University, Bandera St, 12, Lviv, 79013, Ukraine.

Blavt O.: oksanablavt@ukr.net; https://orcid.org/0000-0001-5526-9339; Department of Physical Education, Lviv Polytechnic National University, Bandera St, 12, Lviv, 79013, Ukraine.

Dolnikova L.: dolnikova.lubov@ukr.net; http://orcid.org/0000-0003-0719-2028; Department of Physical Education, Lviv Polytechnic National University, Bandera St, 12, Lviv, 79013, Ukraine.

Cite this article as: Koryahin, V., Turchyn, Ya., Blavt, O., \& Dolnikova, L. (2020). Information Systems of Support of Pedagogical Control in the Physical Education of Students. Teoriâ ta Metodika Fizičnogo Vihovannâ, 20(4), 205-211. https://doi.org/10.17309/tmfv.2020.4.02

Received: 15.07.2020. Accepted: 20.12.2020. Published: 25.12.2020

This work is licensed under a Creative Commons Attribution 4.0 International License

(http://creativecommons.org/licenses/by/4.0). 